\title{
Purification and Characterization of Nucleotide-specific Phosphatases from Soybean Seeds ${ }^{\dagger}$
}

\author{
Zen-ichi YoKoYAMA and Hiroko HIRAI \\ Laboratory of Biochemistry, Kobe Yamate Women's College, \\ Kobe 650, Japan \\ Received July 11, 1988
}

\begin{abstract}
Two kinds of nucleotide-specific phosphatases were separated chromatographically on a DEAEToyopearl $650 \mathrm{M}$ column, and designated as NSP-I and -II. NSP-II was further purified to apparent homogeneity using both affinity and gel-filtration chromatography, but NSP-I purified by the same procedures was not homogeneous on polyacrylamide gel electrophoresis. NSP-I and -II had many similar features in molecular size, optimum $\mathrm{pH}$, heat stability, and substrate specificity. The molecular weight of each enzyme protein was estimated to be approximately 45,000 by molecular sieve chromatography. The optimum pH of each enzyme was 6.5 and showed activity in the wide pH range of 5 9. Neither enzyme hydrolyzed bis( $p$-nitrophenyl)phosphate, adenosine $2^{\prime}: 3^{\prime}$-cyclic-monophosphate, or sugar phosphate, but both showed a marked preference for 5 -mononucleotides as substrate over $p$-nitrophenylphosphate.
\end{abstract}

Phosphatases which catalyze the hydrolysis of numerous phosphate esters are widely distributed in both plant and animal tissues. ${ }^{1,21}$ Soybean seeds are known to contain several kinds of phosphatases of different properties. A nonspecific acid phosphomonoesterase with a $\mathrm{pH}$ optimum of 6.0 was partially purified from defatted soybean meal. ${ }^{3)}$ A violetcolored acid phosphatase was purified from soybeans. ${ }^{4)}$ Soybeans were reported to have three cultivar-specific electrophoretic forms of a seed acid phosphatase. ${ }^{5)}$ Recently, soybean acid phosphatase was completely separated from phytase isolated from cotyledons of germinating seeds and purified to homogeneity. ${ }^{6)}$

In this paper, we describe the presence of nucleotide-specific phosphatases from soybean seeds which have different properties from the published results in certain enzyme characteristics. These data should provide some basic knowledge for additional studies on the soybean seeds phosphatase.

\section{Materials and Methods}

Materials. Soybean seeds (Glycine max, L. var. Tsurunoko) were obtained commercially available. DEAE-cellulose (DE 23) was purchased from Whatman Lid., and DEAE-Toyopearl 650M and Toyopearl HW-55 were purchased from Toyo Soda Mfg. Co. Protein marker kits for the measurement of molecular weight, $5^{\prime}-, 3^{\prime}$-, and $2^{\prime}$-mononucleotides, $2^{\prime}: 3^{\prime}$-cyclic-mononucleotide, ATP, and ADP were purchased from Sigma Chemical Co. All other chemicals were of reagent grade, purchased from Nacalai Tesque, Inc.

Enzyme preparation. Soybean seeds $(1 \mathrm{~kg})$ were immersed in water at $4^{\circ} \mathrm{C}$ overnight and then homogenized with

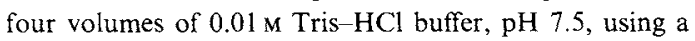
mixer. The homogenate was centrifuged at $10,000 \mathrm{rpm}$ for $30 \mathrm{~min}$, and the supernatant obtained as the crude extract was brought to $30 \%$ saturation by gradual addition of solid ammonium sulfate. After standing for $1 \mathrm{hr}$, the suspension was centrifuged at $10,000 \mathrm{rpm}$ for $30 \mathrm{~min}$, and the precipitate was discarded. Solid ammonium sulfate was further added to $80 \%$ saturation. After standing for $1 \mathrm{hr}$, the precipitate was collected by centrifugation at $10,000 \mathrm{rpm}$ for $30 \mathrm{~min}$, and dissolved in $0.01 \mathrm{M}$ Tris $-\mathrm{HCl}$ buffer, $\mathrm{pH} 7.5$. The resulting solution was dialyzed against the same buffer, and the inner solution was concentrated to $990 \mathrm{ml}$ using polyethylene glycol \#6000 in a visking

\footnotetext{
+ The major part of the work was presented at the Annual Meeting of the Agricultural Chemical Society of Japan at Nagoya, April, 1988.
} 
tube. All the procedures were done at $4^{\circ} \mathrm{C}$.

Phosphatase assay. The assay for phosphatase activity consisted of the following components mixed to a final volume of $1.5 \mathrm{ml}: 75 \mu$ moles of buffer (Tris- $\mathrm{HCl}, \mathrm{pH} 7.5$ ), $15 \mu$ moles of $\mathrm{MgCl}_{2}, 0.75 \mu$ moles of $5^{\prime}$-AMP, enzyme protein, and water. After $30 \mathrm{~min}$ of incubation at $37^{\circ} \mathrm{C}$ the reaction was stopped by adding $0.25 \mathrm{ml}$ of $60 \% \mathrm{HClO}_{4}$. Insoluble material was removed by centrifugation and samples of the supernatant were tested for inorganic phosphate by the method of Itaya and $\mathrm{Ui}^{7)}$ using malachite green. In the enzyme assay the activity varied linearly with enzyme concentration. Specific activity is expressed as $\mu$ moles of inorganic phosphate produced per mg protein and the conditions of the assay indicated above. The other substrates were hydrolyzed as described above for 5'-AMP.

Protein measurement. Protein was measured by the biuret method ${ }^{8)}$ or by the method of Lowry et al., ${ }^{9)}$ and by measuring the absorption at $280 \mathrm{~nm}$.

Chromatography on DEAE-cellulose. DEAE-cellulose column chromatography was done using a $5.0 \times 40 \mathrm{~cm}$ column equilibrated with $0.01 \mathrm{M}$ Tris- $\mathrm{HCl}$ buffer, $\mathrm{pH} 7.5$. Elution was done by the buffer containing $\mathrm{NaCl}$ in a linear gradient of concentration of 0 to $0.6 \mathrm{M}$. The eluate was collected as $21 \mathrm{~g}$ fractions at a flow rate of $0.46 \mathrm{~g} / \mathrm{min}$.

Chromatography on 1st DEAE-Toyopearl $650 \mathrm{M}$. DEAE-Toyopearl column chromatography (1st) was done using a $3.2 \times 24 \mathrm{~cm}$ column equilibrated with $0.01 \mathrm{M}$ Tris$\mathrm{HCl}$ buffer, $\mathrm{pH}$ 7.5. Elution was done with the buffer containing $\mathrm{NaCl}$ in a linear gradient of concentration of 0 to $0.6 \mathrm{M}$. The eluate was collected as $5 \mathrm{~g}$ fractions at a flow rate of $0.30 \mathrm{~g} / \mathrm{min}$.

Chromatography on 2nd DEAE-Toyopearl $650 \mathrm{M}$. The conditions were the same as for the 1st DEAE-Toyopearl $650 \mathrm{M}$ column chromatography except that the elution was done with the buffer containing $\mathrm{NaCl}$ in a linear gradient of concentration of 0 to $0.3 \mathrm{M}$. The eluate was collected as $5 \mathrm{~g}$ fractions at a flow rate of $0.30 \mathrm{~g} / \mathrm{min}$.

Chromatography on Con A-Sepharose. Con ASepharose column (bed volume $5 \mathrm{ml}$ ) was washed with $0.5 \mathrm{M} \mathrm{NaCl}$ in $0.01 \mathrm{M}$ Tris- $\mathrm{HCl}$ buffer, $\mathrm{pH} 7.5$. Elution was done with the buffer containing $0.1 \mathrm{~m} \alpha$-methyl-Dmannoside after washing out the unadsorbed proteins. The eluate was collected as $2.75 \mathrm{~g}$ fractions at a flow rate of $3 \mathrm{~g} / \mathrm{min}$.

Chromatography on Toyopearl HW-55. Toyopearl HW55 column chromatography was done using a $1.7 \times 84 \mathrm{~cm}$ column equilibrated with $0.01 \mathrm{M}$ Tris- $\mathrm{HCl}$ buffer, $\mathrm{pH} 7.5$ containing $0.1 \mathrm{M} \mathrm{NaCl}$. Elution was done with the same buffer. The eluate was collected in fractions of $1.38 \mathrm{~g}$ at a flow rate of $0.14 \mathrm{~g} / \mathrm{min}$.

Chromatography on phosphocellulose. Phosphocellulose column chromatography was done using a $1.6 \times 4.5 \mathrm{~cm}$ column equilibrated with $0.01 \mathrm{M}$ Tris- $\mathrm{HCl}$ buffer, $\mathrm{pH} 7.5$. Elution was done with the buffer containing $\mathrm{NaCl}$ in a linear gradient of concentration of 0 to $0.5 \mathrm{~m}$. The eluate was collected as $1.38 \mathrm{~g}$ fractions at a flow rate of $0.14 \mathrm{~g} / \mathrm{min}$.

Polyacrylamide gel electrophoresis. The electrophoresis was done by the method of Davis ${ }^{10)}$ in $10 \%(\mathrm{w} / \mathrm{v})$ polyacrylamide gel at room temperature at $\mathrm{pH} 8.0$. Twenty-five $\mu \mathrm{g}$ of protein was put on per column. A constant current of $1 \mathrm{~mA}$ per tube was applied for $160 \mathrm{~min}$ and then continued for $80 \mathrm{~min}$ at $2 \mathrm{~mA}$ per tube. The staining was done by the standard procedures using Coomassie brilliant blue $\mathrm{R}-250$.

Molecular weight estimation. The molecular weight of the enzyme was measured by gel filtration on a Toyopearl HW -55 column by the method of Andrews. ${ }^{11}$ The column

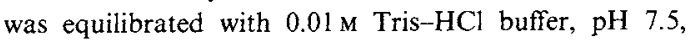
containing $0.1 \mathrm{M} \mathrm{NaCl}$, and the enzymes were chromatographed on the same column previously calibrated with egg albumin $(45,000)$, alcohol dehydrogenase $(150,000)$, and apoferritin $(443,000)$.

\section{Results and Discussion}

\section{Purification of enzymes from soybean seeds A typical elution profile of DEAE-cellulose}

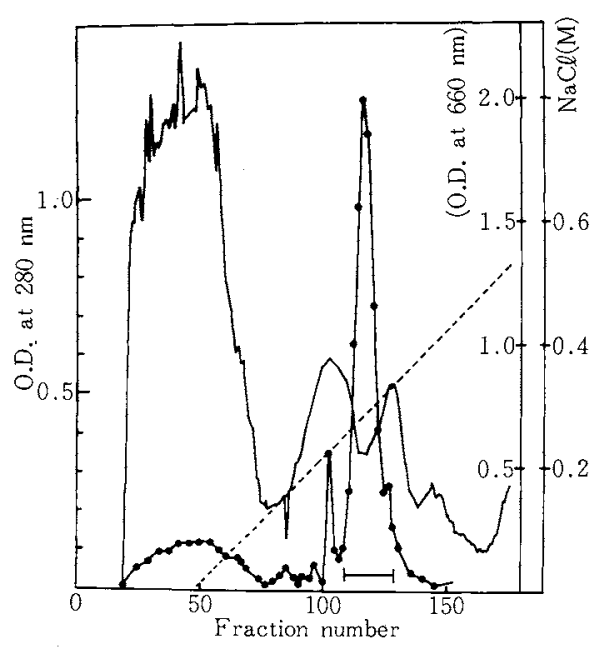

Fig. 1. Column Chromatography of the Crude Enzyme Extract on DEAE-Cellulose.

The enzyme extract was fractionated as described in Materials and Methods. - - , enzyme activity; absorbance at $280 \mathrm{~nm}$; ---.--, $\mathrm{NaCl}$ concentration. 


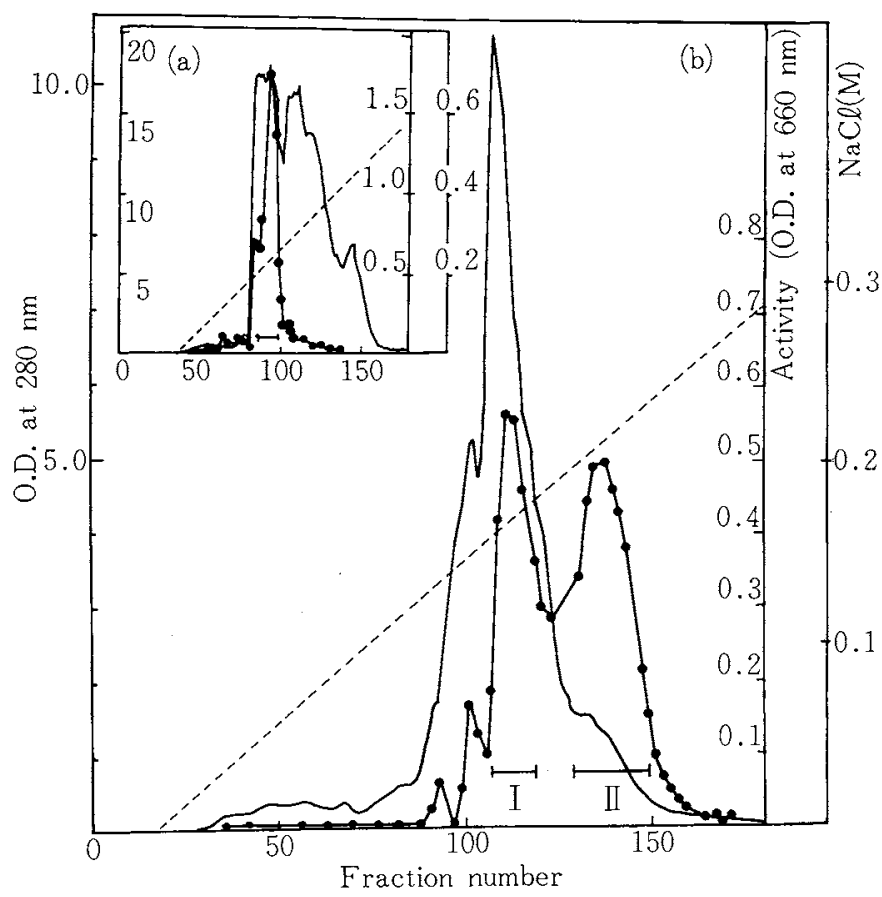

Fig. 2. (a) 1st Column Chromatography of Soybean Phosphatase on DEAE-Toyopearl 650M. (b) 2nd Column Chromatography of Soybean Phosphatase on DEAE-Toyopearl $650 \mathrm{M}$.

Phosphatase fraction shown in Fig. 1 was chromatographed on 1st DEAE-Toyopearl $650 \mathrm{M}$ column (a), and then the fraction containing enzyme activity was collected and rechromatographed as described in Materials and Methods (b). - enzyme activity; - - absorbance at $280 \mathrm{~nm}$; -----, $\mathrm{NaCl}$ concentration.

Table I. Purification Procedure of Soybean Phosphatases

\begin{tabular}{|c|c|c|c|c|c|c|}
\hline Steps & $\begin{array}{c}\text { Volume } \\
(\mathrm{ml})\end{array}$ & $\begin{array}{l}\text { Total } \\
\text { protein } \\
(\mathrm{mg})\end{array}$ & $\begin{array}{c}\text { Total } \\
\text { activity } \\
(\mu \mathrm{mol} \mathrm{Pi})\end{array}$ & $\begin{array}{c}\text { Specific } \\
\text { activity } \\
(\mu \mathrm{mol} \mathrm{Pi} / \mathrm{mg})\end{array}$ & $\begin{array}{l}\text { Yield } \\
(\%)\end{array}$ & Purification \\
\hline Crude extract & 4,000 & 192,400 & 56,304 & 0.29 & 100 & 1 \\
\hline$\left(\mathrm{NH}_{4}\right)_{2} \mathrm{SO}_{4} 30 \sim 80 \% \mathrm{ppt}$ & 990 & 92,813 & 28,710 & 0.31 & 51 & 1.1 \\
\hline DEAE-Cellulose & 325 & 6,877 & 6,208 & 0.90 & 11 & 3.1 \\
\hline DEAE-Toyopearl 650M & 78 & 1,727 & 1,154 & 0.67 & 2 & 2.3 \\
\hline \multicolumn{7}{|l|}{ NSP-I } \\
\hline DEAE-Toyopearl 650M (2nd) & 65 & 696 & 173 & 0.25 & 0.31 & 0.9 \\
\hline Con A-Sepharose & 18 & 2.0 & 65 & 32.09 & 0.12 & 110.7 \\
\hline Toyopearl HW-55 & 14 & 1.6 & 31 & 19.30 & 0.06 & 66.6 \\
\hline \multicolumn{7}{|l|}{ NSP-II } \\
\hline DEAE-Toyopearl 650M (2nd) & 103 & 43 & 141 & 3.28 & 0.25 & 11.3 \\
\hline Con A-Sepharose & 16 & 3.3 & 103 & 30.72 & 0.18 & 105.9 \\
\hline Toyopearl HW-55 & 12 & 1.5 & 61 & 42.02 & 0.11 & 144.9 \\
\hline
\end{tabular}

column chromatography is shown in Fig. 1. Phosphatase eluted as a single peak from the column was pooled, and concentrated to $325 \mathrm{ml}$ using polyethylene glycol \#6000 in a visking tube and chromatographed on the 1st DEAE-Toyopearl 650M column (Fig. 2a). Phosphatase fractions from the chromatography on the DEAE-Toyopearl $650 \mathrm{M}$ column 
were collected and concentrated as described above, then further chromatographed on the 2nd DEAE-Toyopearl 650M column (Fig. 2b). In this chromatography, two enzymatically active peaks were obtained and designated as NSP-I and -II in the order of elution. Each active fraction was collected, and chromatographed using a Con A-Sepharose affinity column. The proteins responsible for the activity were firmly adsorbed to the column, and eluted with $0.1 \mathrm{M} \alpha$-methyl-D-mannoside. These results indicated that the phosphatases separated from soybean seeds are glycoproteins. NSP-I and -II fractions from the chromatography on Con A-Sepharose column were chromatographed on a Toyopearl HW-55 column separately. The elution pattern of NSP-II was parallel with the activity peaks, but NSP-I was not. Then NSP-I was put onto a $p$-cellulose column. NSP-I and -II were electrophoresed on a polyacrylamide gel by the method of Davis. ${ }^{10)}$ As illustrated in Fig. 3, NSP-II migrated as a single band on polyacrylamide gel electrophoresis at $\mathrm{pH} 8.0$, but NSP-I had apparent impurities. The steps of a typical

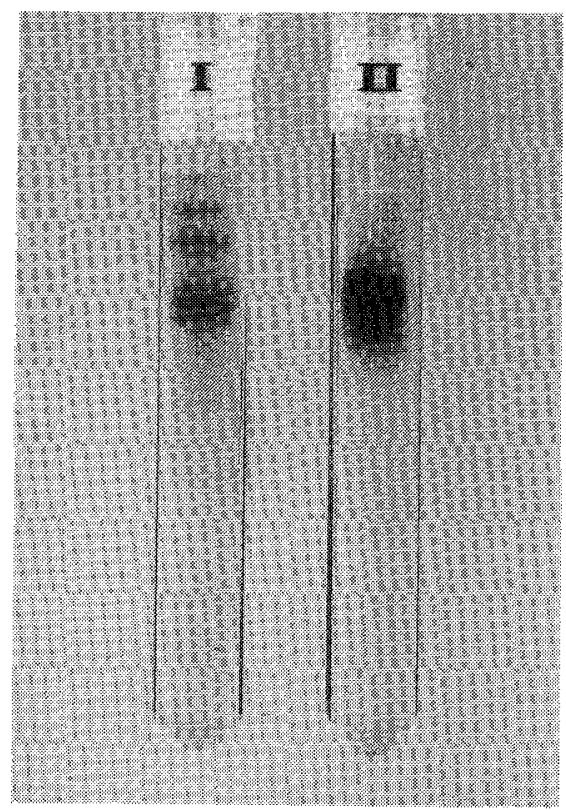

Fig. 3. Polyacrylamide Gel Disc Electrophoresis of Soybean Phosphatases.

Details were described in Materials and Methods. purification of phosphatases are summarized in Table I. The specific activity of NSP-I was of the sample in the step of Toyopearl HW-55, and presented as 67-fold. The actual specific activity after the $p$-cellulose column was not examined. The specific activity of NSP-II increased 145-fold after Toyopearl HW-55 column chromatography. The recovery was 0.06 for NSP-I, and 0.11 for NSP-II.

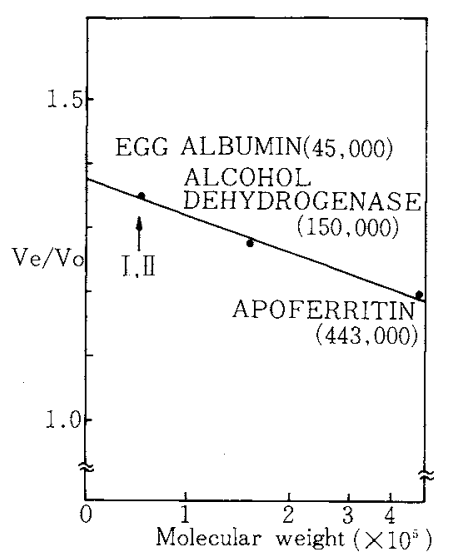

Fig. 4. Molecular Weight Estimation of NSP-I and -II by Toyopearl HW-55.

Details were described in Materials and Methods.
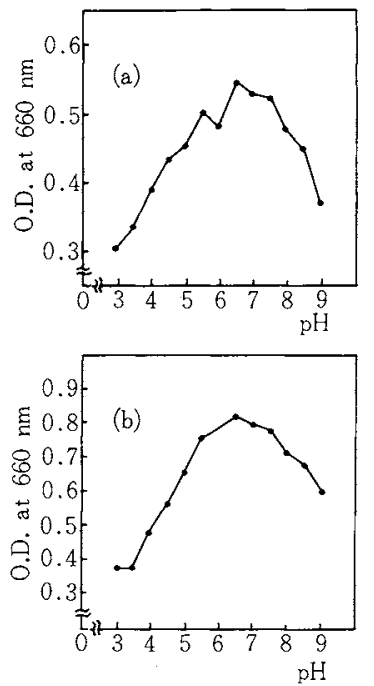

Fig. 5. Effects of $\mathrm{pH}$ on Activity of Purified Soybean Phosphatases.

Details were described in Materials and Methods. (a) NSPI; (b) NSP-II. 


\section{Molecular weight}

The molecular weights of soybean phosphatases were measured by Toyopearl HW-55 gel filtration. Soybean phosphatases NSP-I and -II, separated as described above, had the same molecular size, 45,000 (Fig. 4). This value is similar to those of soybean acid phosphatase $(53,000)^{6)}$ and Phaseolus mungo $(55,000){ }^{12)}$ but differs from those of sunflowers seeds $(103,000),{ }^{13)}$ peanut seeds $(240,000),{ }^{14)}$ and cultured tobacco cells $\left.(74,000) .{ }^{15}\right)$

\section{Effects of $\mathrm{pH}$ on the enzyme activity}

The pH-activity curves of NSP-I and -II indicate the $\mathrm{pH}$ optimum to be 6.5 as illustrated in Fig. 5. Enzyme assays were done from $\mathrm{pH} 3.0$ to 9.0 using $0.1 \mathrm{M}$ succinatesodium hydroxide buffer $(3 \sim 6)$, and $0.1 \mathrm{M}$ Tris-malate buffer $(6.5 \sim 9)$ with $5^{\prime}$-AMP as the substrate. The optimum pH of NSP-I and -II were different from the values $(\mathrm{pH} 3 \sim 5)$ of published reports, ${ }^{6,12 \sim 15)}$ and showed activity in the wide $\mathrm{pH}$ range of $5 \sim 9$.

\section{Effects of metal ions and other reagents}

The effects of various divalent metal ions at a concentration of $1 \mathrm{~mm}$ on the enzyme activity were tested. Neither NSP-I nor -II were affected by $\mathrm{Mg}^{2+}, \mathrm{Ca}^{2+}, \mathrm{Zn}^{2+}$. EDTA, NaF, tartrate, $p \mathrm{CMB}$, adenine and $\mathrm{ATP}$ were not effective to both enzyme activities.

\section{Thermal stability}

NSP-I $(0.07$ of O.D. at $280 \mathrm{~nm})$ and NSP-II $(0.2$ of O.D. at $280 \mathrm{~nm})$ were heated in a water bath for various intervals at $60^{\circ} \mathrm{C}$. Samples of the enzymes were taken, rapidly cooled in ice water, and then tested for residual activity in the enzyme assay. The enzyme gradually lost its activity and $80 \%$ of the original activity remained after $15 \mathrm{~min}$ of heating (data not shown). The enzymes appear to be relatively heat stable.

\section{Substrate specificity}

Substrate specificity of NSP-I and -II are summarized in Table II. NSP-I and -II did not hydrolyze bis( $p$-nitrophenyl)phosphate, $2^{\prime}: 3^{\prime}$ -
Table II. Substrate Specificity of Soybean Phosphatases

\begin{tabular}{lrr}
\hline \multirow{2}{*}{ Substrate } & \multicolumn{2}{c}{ Relative activity $(\%)$} \\
\cline { 2 - 3 } & NSP-I & NSP-II \\
\hline 5'-AMP & 100 & 100 \\
5'-UMP & 156 & 205 \\
3'-AMP & 59 & 54 \\
2'-AMP & 52 & 57 \\
5'-dAMP & 90 & 101 \\
2'(3')-AMP & 3 & 1 \\
ADP & 58 & 51 \\
ATP & 17 & 1 \\
Ribose-5'-phosphate & 0 & 1 \\
o-Phosphoryl ethanolamine & 0 & 0 \\
p-Nitrophenyl phosphate & 51 & 33 \\
Bis-p-nitrophenyl phosphate & 0 & 0 \\
\hline
\end{tabular}

cyclic-AMP, or ribose- $5^{\prime}$-phosphate, and furthermore NSP-II did not hydrolyze ATP. Mononucleotides, especially 5 -mononucleotides, are clearly much better substrates for NSP-I and -II than the other substrates. 3'and $2^{\prime}$-mononucleotides are the next best substrates examined. These results differ greatly from those reported for the soybean acid phosphatase ${ }^{3 \sim 6)}$ and others, ${ }^{12 \sim 15)}$ which do not show a preference for mononucleotides over $p$ nitrophenylphosphate.

\section{References}

1) G. Schmidt, in "The Enzymes," Vol. 5, ed. by P. D. Boyer, H. Lardy and K. Myrback, Academic Press, New York, 1961, pp. $37 \sim 47$.

2) V.P. Hollander, in "The Enzymes," Vol. 4, ed. by P. D. Boyer, Academic Press, New York, 1970, pp. $449 \sim 498$.

3) F. C. Mayer, R. E. Campbell, A. K. Smith and L. L. Mckinney, Arch. Biochem. Biophys., 94, 301 (1961).

4) S. Fujimoto, T. Nakagawa and A. Ohara, Agric. Biol. Chem., 41, 599 (1977).

5) M. B. Gorman and Y. T. Kiang, Crop. Sci., 17, 963 (1977).

6) A. H. J. Ullah and D. M. Gibson, Arch. Biochem. Biophys., 260, 514 (1988).

7) K. Itaya and M. Ui, Clin. Chim. Acta, 14, 361 (1966).

8) A. G. Gornoll, C. S. Bardawill and M. M. David, $J$. Biol. Chem., 177, 751 (1949).

9) O. H. Lowry, N. J. Rosebrough, A. L. Farr and R. J. Randall, J. Biol. Chem., 193, 265 (1951).

10) B. J. Davis, Ann. N.Y. Acad. Sci., 121, Art 2, 560 
(1964).

11) P. Andrews, Biochem. J., 91, 222 (1964).

12) B. Felenbok, Eur. J. Biochem., 17, 165 (1970).

13) H. C. Park and R. L. Van Etten, Phytochemistry, 25,
351 (1986)

14) S. M. Basha, Can. J. Bot., 62, 385 (1983).

15) H. Shinshi and K. Kato, Phytochemistry, 18, 243 (1979). 